\title{
KONFISKACE UMĚLECKÝCH DĚL FYZICKÝCH OSOB V DOBĚ NESVOBODY
}

\author{
ZUZANA LÖBLING
}

\begin{abstract}
The Confiscation of Artworks Owned by Private Persons in the Time of Nazi Persecution

This paper presents an overview of the legal regulation and practice related to the confiscation of works of art in the so called "time of oppression", which is a legal term for a historical period from 30.9.1938 to 4.5.1945 in the territory of the recent Czech Republic. Since the aim of the paper is to serve as a handout helping to understand the historical context by applying the restitutional statute No. 212/2000 Sb., it shows no detailed case study, but concentrates on an instructional overview. After a brief introduction, which explains the aim of the paper and defines its scope, the time of oppression is divided into two phases the so called Second Republic and the Protectorate of Bohemia and Moravia. There is a short characterism of the respective phase and an indicative timeline describing the Era of Protectorate. The following parts deal with the legal regulation and confiscation praxis in more detail. The era of the so called Second Republic is by the nature of things shorter; however, the roots of the oppression practice are well illustrated. On the other hand, the description of the protectorate era required it to be subdivided into three parts: i) an introduction of the basic legal framework; ii) institutions dealing with confiscation; and iii) the disposition of confiscated goods, taking into account the museum practice.
\end{abstract}

Keywords: looted art; gifts for export permission; Vermögensamt; Zentralstelle; Zentralamt; Auswanderungsfond; Treuhandstelle

Klíčová slova: uloupené umění; dary za vývozní povolení; Vermögensamt; Zentralstelle; Zentralamt; Auswanderungsfond; Treuhandstelle

DOI: $10.14712 / 23366478.2021 .31$

\section{1. ÚVOD}

Přestože již bylo ohledně odnímání majetku, a to včetně uměleckých děl, v době nesvobody napsáno množství článků a knih, chyběla mi pro praxi práce, která by přehledně shrnovala základní poznatky, jež by mohly být aplikovány pro restituce dle zákona č. 212/2000 Sb., o zmírnění některých majetkových křivd způsobených holocaustem, ve znění pozdějších předpisů. $Z$ toho důvodu jsem se rozhodla zpracovat stručné shrnutí, které bude poskytovat základní seznámení s tak komplikovanou problematikou, jakou konfiskace a následný osud uměleckých děl bezesporu je. 
Na úvod je třeba ř́íci, že tato práce se zabývá pouze oblastí Protektorátu Čechy a Morava a nebere tedy v potaz odlišnou, ale v mnoha ohledech přesto velmi podobnou právní úpravu konfiskací v Sudetech či ve Slovenské republice, stejně jako neanalyzuje jakoukoliv poválečnou legislativu. $Z$ podstaty je pak zaměřená především na zabrání majetku židovských obyvatel, část popsané právní úpravy a praxe se však dá vztáhnout i na ostatní nacistické konfiskace, at' už byl důvod pronásledování původních vlastníků jakýkoliv. ${ }^{1}$

Tato práce také nemá ambici postihnout celou problematiku majetkových převodů v době nesvobody, přibližuje spíše základní pravidla, která jsou následně aplikována na komoditu uměleckých předmětů, resp. uměleckých děl. Oba tyto termíny jsou používány v textu promiscue a rozumím jimi jakákoliv materiální výtvarná díla movitého charakteru, tj. např. obrazy, sochy či grafiky. Ve svém bádání se tedy primárně nebudu věnovat předmětům uměleckého řemesla nebo jakýmkoliv jiným sběratelským předmětům.

\section{KONFISKACE UMĚLECKÝCH DĚL V DOBĚ NESVOBODY}

Za „dobu nesvobody“ je považováno období od 30. 9. 1938 do 4. 5. 1945, tj. období počínající přijetím Mnichovské dohody a končící začátkem Pražského povstání. Do právního řádu byl tento pojem zaveden ústavním dekretem prezidenta republiky ze dne 8. srpna 1944, č. 11 Úřr. věst. čsl., o obnovení právního pořádku, jeho konec 4. 5. 1945 pak byl následně určen vládním nařízením ze dne 27. 7. 1945, č. 31/1945 Sb., jímž se stanoví konec doby nesvobody pro obor předpisů o obnovení právního pořádku. ${ }^{2}$

$\mathrm{S}$ ohledem na velmi dynamický vývoj právního prostředí ve zkoumaném období a překrývání působnosti jednotlivých institucí, které se na majetkových převodech podílely, rozdělme dobu nesvobody rámcově do následujících fází, jež jsou pro přehlednost opatřena i stručnou charakteristikou:

\section{ETAPA 1: 30. 9. 1938 - 14. 3. 1939 (TJ. OBDOBÍ TZV. 2. REPUBLIKY)}

Tato etapa je s ohledem na ohrožení demokracie charakterizována (více či méně organizovaným) vystěhovalectvím a s ním spojenými prodeji majetku pod cenou, snahou o jeho vývoz, dary za vývozní povolení a depozity uměleckých děl u státních institucí.

\section{ETAPA 2: $15.3 .1939-4.5 .1945$ (TJ. OBDOBÍ PROTEKTORÁTU)}

ETAPA 2.1: 15.3. 1939 - 21. 6. 1939 (TJ. OD ZAHÁJENÍ OKUPACE)

Přes pokračování praxe uvedené $\mathrm{v}$ etapě 1 se zde projevovala snaha okupační správy zdokumentovat rozsah především židovského majetku a zamezit jeho zašantročení ${ }^{3}$ do českých rukou. Začaly konfiskace gestapem.

\footnotetext{
Viz např. výklad týkající se Úřadu říšského protektora nebo gestapa.

Období od 29. 9. 1938 do 4. 5. 1945 je považováno za rozhodné období i v $\$ 3$ zákona č. 212/2000 Sb.

Jak v rámci SVOČ, tak v rámci recenzního řízení mi bylo vytýkáno použití slova „zašantročení“. Úmyslně ho však $\mathrm{v}$ textu ponechávám, nebot’ jde z mého pohledu o výstižný popis způsobu majetkového převodu. Vzhledem $\mathrm{k}$ tomu, že je užit i v popisu skutkové podstaty trestného činu zneužívání vlastnictví uvedené
} 


\section{ETAPA 2.2: 22. 6. 1939 - 4. 3. 1940 (TJ. OD VYDÁNÍ NAŘÍZENÍ ŘÍŠSKÉHO PROTEKTORA O ŽIDOVSKÉM MAJETKU) ${ }^{4}$}

Došlo ke stanovení základního právního rámce monitoringu židovského majetku a omezení nakládání s ním. Pokračovala praxe uvedená v předešlých etapách.

\section{ETAPA 2.3: 5. 3. 1940 - 15. 10. 1941 (TJ. OD VYDÁNÍ 1. NAŘÍZENÍ ŘÍŠSKÉHO PROTEKTORA O PÉČI O ŽIDOVSKÉ ORGANIZACE) $)^{5}$}

V této etapě začala na základě Nařízení o péči o Židy reorganizace židovských organizací, které se měly podílet na tzv. konečném řešení. Židé byli dále povinni deponovat v předpisech uvedené majetkové hodnoty, které byly následně rozprodávány.

\section{ETAPA 2.4: OD 16. 10. 1941 (TJ. OD 1. TRANSPORTU DO LODŽE) DO 4. 5. 1945}

V souvislosti s deportacemi docházelo k propadnutí židovského majetku ve prospěch Říše. Nadále pokračovala konfiskace $\mathrm{v}$ důsledku trestněprávní perzekuce.

Přestože další text nebude př́ísně strukturován podle výše uvedených etap, umožňují nám udělat si schematický úvodní obrázek o popisovaném období a ve zkratce identifikovat problematiku, kterou se budeme podrobněji zabývat níže.

\section{OBDOBÍ 2. REPUBLIKY}

Vzhledem ke vzrůstajícímu ohrožení ze strany Německé říše, které vyvrcholilo anšlusem Rakouska dne 12. 3. 1938, začali potenciální odpůrci nacistického režimu již před podpisem Mnichovské dohody pocit'ovat zvýšené nebezpečí. Toto nebezpečí se odrazilo jak ve zvýšené imigraci, která se v Československu projevovala již od nástupu Hitlera k moci v roce 1933, tak později i snahami o vystěhování ohrožených skupin obyvatelstva co nejdál od politického vlivu nacistů. ${ }^{6}$

S uprchlictvím je tak nezbytně nutně spojena snaha o vyvezení pokud možno co největšího majetku za hranice ohroženého státu, popřípadě jeho uložení pro pozdější vyzvednutí. V mnoha případech však docházelo i k nevýhodným prodejům, které bychom z dnešního pohledu mohli kvalifikovat jako relativně neplatné podle $\S 587$ občanského zákoníku, tj. právní jednání učiněná pod tlakem vis compulsiva, popř́ípadě jako neplatné z důvodu zneužití tísně jednající osoby dnes upravené v ustanovení § 1796 občanského zákoníku. Odhlédnout nelze ani od násilného jednání a divokých „,arizací“, které se

v § 229 zákona č. 40/2009 Sb., trestní zákoník, ve znění pozdějších předpisů, nejedná se dle mého názoru o hovorový nebo hanlivý výraz.

4 Viz Nařízení říšského protektora v Čechách a na Moravě o židovském majetku; platnost 21. 6. 1939; účinnost 22. 6. 1939; zrušeno 17. 6. 1946 (dále jen jako „Nařízení o židovském majetku“), RP14/39. Částečná zpětná účinnost Nařízení o židovském majetku byla upravena v jeho § 12 odst. 2 a 3.

5 Viz Nařízení Říšského protektora v Čechách a na Moravě o péči o Židy a židovské organisace; platnost 5. 3. 1940; účinnost 10. 3. 1940; zrušeno 17. 6. 1946 (dále jen jako „Nařízení o péči o Židy“), RP09/40.

6 Více viz např. FRANKL, M. Druhá republika a židovští uprchlíci. In: POJAR, M. - SOUKUPOVÁ, B. ZAHRADNÍKOVÁ, M. (eds.). Židovská menšina za druhé republiky. Praha: Židovské muzeum, 2007, s. $45-56$. 
začaly živelně projevovat již v tomto období, ${ }^{7}$ na síle ale nejvíce nabyly v čase těsně po okupaci.

V souvislosti s uměleckými díly jsou pro toto období charakteristické tzv. dary za vývozní povolení. Tato praxe se dle literatury využívala již před Mnichovskou dohodou, a to na základě nařízení Národního výboru československého č. 13/1918 Sb., ${ }^{8}$ později pak na základě výnosu Zemského výboru z 27. 10. 1937 č. 255. Za druhé republiky bylo vydáno opatření Stálého výboru Národního shromáždění ze dne 27. ř́inna 1938 č. $255 \mathrm{Sb}$., o ochraně věcí umělecky nebo památkově zvláště hodnotných. Dle $\S 1$ tohoto opatření mohla být umělecky nebo památkově zvláště hodnotná díla (zejména tvořila-li soubor) vyvezena do ciziny nebo na území obsazené cizí mocí jen se svolením ministerstva školství a národní osvěty. Toto svolení bylo uděleno pouze tehdy, nepříčilo-li se ,veřejným zájmům “, v ustanovení § 2 opatření bylo ale explicitně uvedeno, že ,,[p]ři posuzování veřejných zájmů postupuje úřad podle volného uváženi “. V praxi byla hlavní role při rozhodování o povolení vývozu svěřena místně příslušnému památkovému úřadu, své vyjádření k vývozu zde však dávaly i jednotlivé veřejné galerijní instituce. ${ }^{9} \mathrm{Z}$ vyvážené sbírky byla vybrána nejvýznamnější díla, u kterých bylo následně požadováno, aby byla bud' darována prrímo státu, nebo aby byla uzavřena kupní smlouva s některou z veřejných sbírek. Dle Vlnase ale ,ze sekundárních poválečných svědectví vyplývá, že při této príležitosti se v některých připadech uzavírala neformální ústní dohoda o budoucí restituci děl pưvodním majitelìm ".10 Zda se takováto dohoda skutečně uzavírala nebo zda podobné tvrzení představovalo pouze snahu dotčených osob zlepšit svou nepř́iznivou poválečnou situaci, již bohužel nedokážeme ověřit, faktem ale zůstává, že po vydání zákona č. 212/2000 Sb., o zmírnění některých majetkových křivd způsobených holocaustem, bylo zprvu odmítáno navracet umělecké předměty darované za vývozní povolení. Tato praxe se změnila až na základě rozsudku Nejvyššího soudu ve věci Bloch, sp. zn. 19 Co 95/2010.

Vzhledem k tomu, že z území ohroženého státu nebylo možné vyvézt celé sbírky, které měly samozřejmě větší hodnotu než jednotlivá díla samostatně, rozhodli se někteří majitelé uložit svá díla na základě smlouvy schovací11 do veřejných sbírek, odkud měla být po pominutí nebezpečí vyzvednuta. ${ }^{12}$ Ve většině príípadů však byla díla v průběhu

7 Více viz např. RATAJ, J. Česká politika v druhé republice - kritický pohled na „neznámé“ češství. In: POJAR, M. - SOUKUPOVÁ, B. - ZAHRADNÍKOVÁ, M. (eds.). Židovská menšina za druhé republiky. Praha: Židovské muzeum, 2007, s. 21-44.

8 Toto nařízení Národního výboru československého sloužilo jako podklad k povolování vývozů uměleckých a historických památek, během kterého se rozvinula neformální praxe darů za vývozní povolení. Více k této problematice viz KROČILOVÁ, Z. Dary za vývozní povoleni v době nesvobody a problematika jejich restituce v České republice. XIII. ročník SVOČ, kategorie doktorské studium.

9 Více viz KUKLÍK, J. a kol. Jak odškodnit holokaust?: problematika vyvlastnění židovského majetku, jeho restituce a odškodnění. Praha: Karolinum, 2015, s. 78.

10 Více viz JANATKOVÁ, A. - VLNAS, V. Pražská národni galerie v protektorátu Čechy a Morava. Praha: Národní galerie v Praze, 2013. V souvislosti s citovaným tvrzením je třeba dodat, že prof. PhDr. Vít Vlnas, Ph.D., byl dlouholetým zaměstnancem Národní galerie v Praze (dále jen jako „NGP“), který byl mj. v letech 2013-2014 pověřen jejím vedením jako generální ředitel.

11 Za tímto účelem byly uzavírány smlouvy schovací dle ust. § 957 a násl. Všeobecného občanského zákoníku.

12 Jako deposita byly do NGP uloženy např. části sbírek Josefa Pollaka, Selmy Baštýřové či Richarda Morawetze. 
války zabavena a prohlášena za tzv. Reichseigentum. Přestože sice depozita neochránila vlastnické právo svých původních majitelů, můžeme tuto praxi zpětně hodnotit kladně, protože zajistila, že podstatné části sbírek zůstaly pohromadě na jednom místě, odkud pak mohly být vydány př́padným dědicům. Naproti tomu úschovy u soukromých osob ${ }^{13}$ již celistvost sbírek zajistit nedokázaly, díla byla vyzvedávána okupační správou a rozdělena podle zavedené praxe (viz níže).

\section{PROTEKTORÁTNÍ OBDOBÍ}

Vzhledem ke komplexnosti a mnohdy nepřehlednosti nakládání s majetkem konfiskovaným z různých zdrojů jsem se rozhodla vedle základního dělení na etapy provedeného hned $\mathrm{v}$ úvodu 2 . kapitoly rozdělit tento podrobný výklad na 3 části: i) úvodem bude podán obecný právní rámec, na jehož základě byly konfiskace uměleckých děl prováděny, ii) následně budou stručně představeny jednotlivé instituce, které se $\mathrm{v}$ rámci daných právních norem pohybovaly a iii) závěrem bude podán doplňující výklad vykreslující situaci v muzeálním prostředí a na uměleckém trhu.

\subsection{ZÁKLADNÍ PRÁVNÍ RÁMEC KONFISKACÍ}

Dle výnosu vůdce a řišského kancléře ze dne 16. 3. 1939, o Protektorátu Čechy a Morava, došlo k zásadní státoprávní změně, na základě které se zbytek Česko-Slovenska dostal pod ochranu Německé říše. Již podle čl. II tohoto výnosu byli obyvatelé Protektorátu rozděleni do dvou základních skupin, a to na i) německé státní př́slušniky, kteří podléhali německé soudní pravomoci a pro něž platila ustanovení zákona z 15. 9. 1935 o ř́řských občanech a ustanovení na ochranu německé krve a německé cti, a na ii) skupinu ostatních obyvatel Čech a Moravy, kteří se stali státními př́slušníky Protektorátu Čechy a Morava. V této souvislosti je třeba stručně zmínit i to, že čl. XII výnosu o Protektorátu stanovil, že: , [p]rávo, platné té doby v Čechách a na Moravě, zůstává v účinnosti, pokud neodporuje smyslu převzetí ochrany Německou řiší “. Výnosem byl tedy zaveden i právní dualismus, $\mathrm{v}$ rámci kterého byla autonomie českého práva výrazně omezována zásahy okupační správy, jež prostřednictvím říšského protektora rozhodovala, které právní předpisy a v jakém rozsahu zůstanou platné. ${ }^{14}$ Německý právní rád byl tak fakticky nadřazen právnímu řádu protektorátnímu. ${ }^{15}$

Židé byli v Protektorátu postupně zbavováni jakýchkoliv práv a postaveni mimo právní ochranu. Jelikož nebyly na území Protektorátu plošně aplikovány tzv. Norimberské zákony (ty byly aplikovány pouze u německých státních př́slušníků, viz výše), ${ }^{16}$ měla být původně tzv. židovská otázka řešena normami protektorátní

13 Např. sbírka Richarda Poppera či Emila Picka.

14 Viz TAUCHEN, J. Právní ŕád a publikace právních předpisů v Protektorátu Čechy a Morava. In: Dny práva 2012 - Days of Law 2012. Brno: Masarykova univerzita, 2013, s. 701-716.

15 Viz PETRŮV, H. Zákonné bezpráví: Židé v Protektorátu Čechy a Morava. Praha: Auditorium, 2011, s. 37.

16 Pro ostatní obyvatelstvo Protektorátu byla pravidla obdobná Norimberským zákonům zaváděna prostřednictvím speciálních norem, viz např. Nařízením o židovském majetku. 
vlády. ${ }^{17}$ Nakonec však byla pravomoc nad židovským obyvatelstvem rozdělena tak, že majetková perzekuce (vzhledem ke své ,atraktivitě“) a prííprava genocidy byla upravena předpisy okupační správy, naproti tomu opatření vyřazující židovské obyvatelstvo z veřejného života byla ponechána v gesci protektorátních institucí. ${ }^{18}$ Problematické pak bylo nejenom toto rozdělení pravomocí, ale i narušení samotného konceptu legality vydávaných předpisů, které často nebyly řádně publikovány nebo působily retroaktivně. ${ }^{19}$ Ilustrativním př́kladem takové dodatečné aprobace protektorátní praxe budiž odebírání občanství a ztráta majetku Židů, kteří se trvale zdržovali v cizině - toto pravidlo se na Židy, kteří byli státními př́slušníky Protektorátu, uplatňovalo již od samého počátku deportací na podzim roku 1941, nařizení upravující tuto otázku však bylo vydáno až $\mathrm{v}$ roce $1942 .{ }^{20}$

Soustředíme-li se na osud židovského majetku v protektorátním období, zjistíme, že první předpisy ohledně jeho zajištění byly vydány již krátce po okupaci šéfy civilních správ u vojenských skupin v Čechách (dne 29. 3. 1939) a na Moravě (dne 20. 3. 1939). ${ }^{21}$ Na tato přechodná nařízení následně přímo navázalo Nařízení o židovském majetku ze dne 21. 6. 1939, které představovalo základní kámen pro konfiskace, omezování vlastnického práva a jeho převody a které zároveň ve svém $§ 11$ výše uvedená nařízení zrušilo a nahradilo. Pro zkoumání konfiskace uměleckých děl jsou pak důležité především tyto jeho části:

- Dle $\S 5$ byli Židé (ale i židovské podniky a židovská osobní sdružení) povinni do 31. 7. 1939 přihlásit předměty z drahých kovů, drahokamy a perly, stejně jako ,,jiné drahocenné a umělecké předměty, pokud cena jednotlivého predmětu nebo sbírky předmětů převyšuje částku K 10.000,- “ u Národní banky pro Čechy a Moravu. Zakázáno bylo dále takovéto předměty nabývat, zcizit či zastavit bez povolení devizového referátu protektorátního ministerstva financí. Tyto zákazy se však nevztahovaly na právní jednání mortis causa.

- V $§ 6$ byla uvedena definice Žida, která odpovídala kritériím židovství podle tzv. norimberských zákonů. V § 7 jsou pak definována kritéria, na základě kterých bylo rozhodnuto, které podniky se považují za židovské.

- $\$ 9$ obsahoval úpravu správců majetku, tzv. Treuhändlerů, kteří podléhali dozoru a prŕikazům říšského protektora. Tito správci nahradili důvěrníky a vnucené správce dosazené podle protektorátních předpisů. ${ }^{22}$

17 Viz KUKLÍK, c. d., s. 82

18 Tato část omezujících opatření, jakkoliv se na první pohled jeví jako spíše ,zbytková“, je však stejně důležitá jako samotná majetková perzekuce, která Židy postupně zbavovala majetku. Předpisy vylučující tyto osoby z veřejného života jim totiž bránily jakýkoliv majetek znovu, byt' v malých částech, nabýt. Tento princip je dobře popsán na př́ipadu Richarda Poppera - viz ERBEN, V. - KREJČA, O. Sbirka Richarda Poppera: obrazy ze židovských sbírek v Národni galerii v Praze. Praha: Centrum pro dokumentaci majetkových převodů kulturních statků obětí II. světové války, 2016.

19 Viz KUKLÍK, c. d., s. 84.

20 Viz tamtéž, s. 85.

21 Viz tamtéž, s. 95.

22 Viz vládní nařízení č. 87/1939 Sb., o správě hospodářských podniků a o dozoru nad nimi; platnost 31.3. 1939; účinnost 31. 3. 1939; zrušeno 15. 11. 1946. 
- Pro konfiskaci uměleckých předmětů je velmi významným ustanovení § 10, které stanovuje sankce za nedodržování Nařízení o židovském majetku. Tyto sankce spočívaly jak v trestu vězení, tak v peněžité pokutě nebo zabavení majetku. Pokus byl trestný. Při ukládání trestů se postupovalo podle říšskoněmeckého trestního práva, řízení se vedlo u německých soudů. Není tedy žádným překvapením, že v konfiskacích na základě tohoto ustanovení sehrálo klíčovou roli gestapo.

- Dle § 12 nabylo Nařízení o židovském majetku účinnosti 22. 6. 1939, jeho ustanovení týkající se nemovitostí, hospodářských závodů a cenných papírů však nabyla účinnosti retroaktivně od 15.3. 1938 s tím, že všechny v mezidobí učiněné obchody musely být dodatečně schváleny.

K provedení Nařízení o židovském majetku bylo v průběhu času vydáno celkem 9 prováděcích výnosů. $Z$ perspektivy zkoumání převodů uměleckých děl jsou významné především následující:

- Druhý prováděcí výnos (VOBl. RP, 1939, s. 318), který dával ve svém § 6 určeným protektorátním úrúadům možnost umělecká díla zabavit ${ }^{23} \mathrm{a} s$ těmito volně nakládat.

- Třetí prováděcí výnos (VOBl. RP, 1940, s. 44), který upravil zákaz zcizování uměleckých předmětů, které mohly být od 29.1. 1940 prodány se svolením říšského protektora pouze podniku Hadega, obchodní společnost s r. o.

- Pátý prováděcí výnos (VOBl. RP, 1940, s. 81), který ukládal Židům povinnost uložit akcie a jiné ,pevně zúročitelné hodnoty “ a cenné papíry do depot znějících na jejich jméno. Stejná povinnost se pak vztahovala i na drahé kovy, drahokamy, perly a umělecké předměty, jejichž hodnota přesahovala K 10.000,-..24

Vzhledem $\mathrm{k}$ tomu, že $\mathrm{v}$ praxi docházelo $\mathrm{k}$ zašantročování uměleckých předmětů, které však nacisté měli v úmyslu na ,území, které tradičně patřilo $k$ velkoněmeckému prostoru ", částečně chránit, a nikoliv drancovat jako v jiných okupovaných státech, bylo dne 1. 10. 1940 vydáno nařízení ŕíšského protektora o ochraně kulturních památek v Protektorátu Čechy a Morava (dále jen jako „Nařízení o ochraně památek“). Tímto nařízením skončila platnost dřivějších protektorátních předpisů o povolování vývozů, které měl napřrišstě v gesci pouze Úřad říšského protektora. Význam tohoto nařízení tkví také v tom, že na rozdíl od opatření Stálého výboru Národního shromáždění ze dne 27. ř́ijna 1938 č. 255 Sb., o ochraně věcí umělecky nebo památkově zvláště hodnotných, obsahovalo toto nové nařízení také definici uměleckých památek, kterými byly „předměty hodnoty umělecké nebo vlastenecké nebo zvláśtního významu pro vědu “. Obdobně jako v Nařízení o židovském majetku se porušení i tohoto nařízení trestalo jak vězením, tak zabavením dotčených uměleckých děl. ${ }^{25}$

23 A to zejména podle daňových předpisů a předpisů o poplatcích. Umělecká díla tak byla často dražena za účelem úhrady daňových nedoplatků.

24 Vyhláškou ř́šského protektora ze dne 2. 3. 1940 a vyhláškou protektorátního ministerstva financí ze dne 13. 9. 1940, které byly vydány k provedení pátého prováděcího výnosu, byly vyňaty z depositní povinnosti některé věci osobní potřeby, mezi nimi např. snubní prsteny či náramkové hodinky.

25 Viz KUKLÍK, $c$. d., s. 127. 


\subsection{1 ÚŘAD ŘÍŚSKÉHO PROTEKTORA}

Jak již bylo v předcházejícím textu několikrát zmíněno, nejdůležitější kompetence při povolování dispozic a případné vyvlastňování uměleckých děl spadaly pod Úřad říšského protektora, který představoval vrchol okupační správy. Vzhledem k tomu, že veškeré konfiskáty byly považovány za tzv. Reichseigentum, musely se všechny ostatní institucionální složky okupační moci podrobit tomuto úřadu. ${ }^{26}$ Od roku 1941 byl pak veškerý nepřátelský majetek, a to včetně uměleckých děl, předáván do správy tzv. Majetkového úřadu u rríšského protektora (Vermögensamt beim Reichsprotektor in Böhmen und Mähren; dále jen jako ,, Vermögensamt “), ${ }^{27} \mathrm{z}$ nějž však byl některý dotčený majetek po zahájení deportací Židů převáděn do tzv. Auswanderungsfondu. ${ }^{28}$

V souvislosti s Úřadem říšského protektora je třeba i zmínit tzv. Bodenamty, které měly na starosti konfiskaci nejenom zemědělské půdy, ale i všech nemovitostí s půdou spojených. Typicky se tak jednalo o různé zámky a letní sídla, ve kterých se nacházelo i velké množství uměleckých děl a starožitností. Tyto cenné předměty byly za účelem další dispozice sváženy do Prahy a podle svého původu rozdělovány mezi Vermögensamt a Auswanderungsfond. ${ }^{29} \mathrm{~V}$ návaznosti na nepřehlednou institucionální situaci a neustále se opakující problémy se zašantročováním uměleckého majetku, byl v roce 1942 zastupujícím ř́šským protektorem Kurtem Daluegem zřízen tzv. Einsatzstab I, v jehož čele stanul Helmut Rinnebach (proto se o něm mluvilo také jako o Einsatzstabu Rinnebach), který s Bodenamtem úzce spolupracoval. Úkolem tohoto Einsatzstabu byla především inventarizace uměleckého majetku nacházejícího se na českých a moravských zámcích. Kromě této hlavní činnosti se však Einsatzstab I věnoval i ohodnocování uměleckého majetku ve správě Vermögensamtu a Auswanderungsfondu.

Aby byl přehled úplný, je třeba na tomto místě dodat, že v říjnu 1942 byl zřízen i tzv. Einsatzstab II pod vedením Waltera Jurka (označoval se proto jako Einsatzstab Jurk). Tento Einsatzstab měl na starosti využití zabavených bytů pro potřeby rodin z Říše a vybavení těchto bytů konfiskovaným nábytkem a méně hodnotnými uměleckými předměty. ${ }^{30}$

\subsubsection{GESTAPO}

Gestapo bylo od počátku velmi intenzivně zapojeno do organizace vystěhovalectví, když dohlíželo mimo jiné na to, aby každý z uvažovaných emigrantů splnil veškeré mu uložené povinnosti (a to včetně deponování majetku u vybraných bank a správců), a následně vydávalo povolení k výjezdu do zahraničí. Zároveň však prová-

26 Policejní represivní aparát byl sice řízen př́slušnými ústředními bezpečnostními úřady, konfiskáty však byly (nebo spišš měly být) odevzdávány pod správu Úřadu říšského protektora.

27 Vermögensamt byl zř́ízen Výnosem ř́šského protektora ze dne 2. 9. 1941.

28 Tzv. Auswanderungsfond byl speciální veřejnoprávní majetkový fond, který byl nositelem majetku Ústředny pro židovské vystěhovalectví, tzv. Zentrallstelle. Oběma těmto institucím se budu blíže věnovat v kapitole 4.2 .3 níže.

29 Viz KUKLÍK, c. d., s. 119 a násl.

30 K Einsatzstabům více viz KUKLÍK, c. d., s. 134; a SEDLÁKOVÁ, M. Úloha tzv. Einsatzstabů při zcizování židovského majetku. In: MILOTOVÁ, J. - LORENCOVÁ, E. (eds.). Terezinské studie a dokumenty 2003. Praha: Sefer, Institut Terezínské iniciativy, 2003, s. 263-288. 
dělo konfiskaci ${ }^{31}$ majetku všech osob, které se bez platného povolení zdržovaly mimo území Protektorátu (a to i retroaktivně), a dále zajišt’ovalo propadlé předměty dle $\S 10$ Nařízení o židovském majetku. V neposlední řadě pak gestapo konfiskovalo i majetek osob, které spáchaly některý ze zločinů proti Říši. Při své činnosti spolupracovalo také velmi úzce s tzv. Devisenschutzkommandy a Zollfahndungsstellen, které byly pověřeny dohledem nad dodržováním devizových a celních předpisů, a to včetně pátrání po zatajovaných uměleckých dílech $\mathrm{v}$ prípadech nelegálních odchodů do zahraničí. ${ }^{32}$

Konfiskáty byly ve spolupráci s různými správcovskými společnostmi spravovány hospodářskými odděleními gestapa nebo předávány Úřadu řišského protektora. Umělecká díla však často představovala jablko sváru, nad kterým žádná z dotčených institucí (a zainteresovaných osob) nechtěla ztratit svůj vliv. Byla tedy vyvolána jednání, jejichž výsledkem byla v prosinci 1940 dohoda, na základě které se gestapo zavázalo zabavené „hodnotné“ umělecké předměty Úřadu říšského protektora hlásit, a umožnit mu tak spolurozhodovat o jejich osudech. ${ }^{33}$

Jiná situace nastala po zahájení deportací v říjnu 1941 - tehdy gestapo začalo intenzivně spolupracovat s Zentralstelle (resp. jejím Auswanderungsfondem), ${ }^{34}$ které měl být předáván majetek deportovaných osob, jenž nebyl obsažen ve Vermögenserklärung odevzdávaném na seřadišti.

\subsubsection{SPECIÁLNÍ INSTITUCE ZABÝVAJÍCÍ SE ŽIDOVSKÝM VYSTĚHOVALECTVÍM A DEPORTACEMI}

Za účelem zpřehlednění organizace židovského vystěhovalectví byla Výnosem říšského protektora ze dne 15. 7. 1939 zřízena po vídeňském vzoru Ústředna pro židovské vystěhovalectví (tj. Zentralstelle für jüdische Auswanderung; dále jen jako „Zentralstelle"), jejíž pravomoc v oblasti legální židovské emigrace byla od 16. 2. 1940 rozšířena z Prahy a jejího okolí na celé území Protektorátu. ${ }^{35}$ Prvním velitelem Zentrallstelle byl stanoven Franz Walter Stahlecker (velitel bezpečnostní policie), personální základnu pak tvořili mj. i protektorátní úředníci či vystěhovalecké oddělení Židovské náboženské obce v Praze. ${ }^{36}$ Dne 12. 8. 1942, tj. v době probíhajících deportací, byla Zentralstelle přejmenována na Úřad pro řešení židovské otázky (tj. Zentralamt für die Regelung der Judenfrage in Böhmen und Mähren; dále jen jako ,Zentralamt"), který pod tímto názvem působil až do konce války.

31 Jelikož se jednalo o agendu poměrně náročnou, vznikaly u úřadoven gestapa samostatné konfiskační referáty - u hlavní úřadovny pražského gestapa to byl např. tzv. Beschlagnahmreferat, který úzce spolupracoval s Executivereferat, který jednotlivé konfiskace fakticky prováděl - viz KUKLÍK, c. d., s. 104.

32 Více tamtéž, s. 103.

33 Více tamtéž, s. 127. U Úřadu říšského protektora byla umělecká díla inventarizována ve skupině 8 II. oddělení Úřadu pro hospodářské a finanční věci; o nakládání s nimi pak spolurozhodovalo IV. oddělení (pozdější oddělení I/10) pod vedením Dr. Fuchse. Protektor byl o konfiskacích uměleckých děl informován skrze svůj sekretariát, kde se této problematice věnoval hrabě von Waldburg.

34 Více o těchto institucích sloužících k zajištění židovského vystěhovalectví a deportací viz kapitola 4.2.3. níže.

35 Viz DOK. č. 252, 15. Juli 1939. In: LÖW, A. (ed.). Die Verfolgung und Ermordung der europäischen Juden durch das nationalsozialistische Deutschland 1933-1945: Band 3 Deutsches Reich und Protektorat September 1939 - September 1941. Oldenbourg: Oldenbourg Wissenschaftsverlag, 2012.

36 Více viz PETRŮV, c. d., s. 160. 
Činnost Zentralstelle je možné rozdělit do dvou fází:

1. Od svého vzniku do ř́jna 1941, kdy přebírala majetek Židů, kteří se z Protektorátu legálně vystěhovali. ${ }^{37}$ Po vydání Nařízení o péči o Židy spravovala Zentralstelle i majetek rušených židovských spolků, nadací a obcí.

2. Od zahájení deportací v ř́ijnu 1941 do konce války, kdy byla Zentralstelle oprávněna $\mathrm{k}$ likvidaci majetku deportovaných osob. Ten byl zpočátku přebírán na základě generální plné moci udělované obět'mi před nástupem do transportu, ${ }^{38}$ které se však staly bezpředmětnými po nabytí účinnosti předpisu zbavujícího deportované protektorátního občanství, ${ }^{39}$ jež s sebou neslo propadnutí majetku ex lege.

Pro zajištění fungování Zentralstelle byl dle Nařízení o péči o Židy zřízen Vystěhovalecký fond pro Čechy a Moravu (tj. Auswanderungsfond für Böhmen und Mähren; dále jen jako „,Auswanderungsfond"), jakožto majetkový veřejnoprávní fond zřízený podle ř́šského práva, který byl nositelem majetku Zentralstelle. Vzhledem k tomu, že Auswanderungsfond měl především sloužit k financování řešení tzv. židovské otázky, byl zbaven povinnosti platit jakékoliv majetkové dávky. Na základě Třetího nařízení říšského protektora o péči o Židy a židovské organizace ze dne 19. 11. 1941 (VOBl. RP, 1941, s. 642), tedy již v době, kdy Auswanderungsfond přebíral majetek deportovaných osob, byla také upravena práva věritelů a jiných oprávněných $\mathrm{k}$ původně židovskému majetku - veškerá takováto práva zanikla ex lege a dotčené osoby mohly žádat o odškodnění př́mo u Auswanderungsfondu. Pro jakékoliv civilněprávní spory, kterých byl Auswanderungsfond účastníkem, byly však př́slušné pouze německé soudy.

Jak již bylo zmíněno výše, personálně byla Zentralstelle zajišt'ována i ze strany pražské židovské náboženské obce. Dělo se tak na základě Nařízení o péči o Židy, které bylo vydáno dne 5.3. 1940 a dle kterého měly všechny náboženské obce povinnost ,pečovat o veškeré Židy v oboru vystěhovalectvi “. Náboženská obec v Praze hrála díky svému historicky danému vedoucímu postavení, ale také např. i díky podrobným kartotékám židovského obyvatelstva, ${ }^{40}$ nezanedbatelnou úlohu v nakládání s židovským majetkem a v organizaci pozdějších deportací. Za tímto účelem byla pražská náboženská obec na popud protektorátních úřadů postupně reorganizována a všechny její tradiční úlohy byly upozaděny. Tento proces pak vyvrcholil rozhodnutím ze dne 8. 2. 1943, kterým bylo přistoupeno ke zrušení veškerých ostatních náboženských obcí a k přenesení jejich zbývající agendy na nově zřízenou Židovskou radu starších v Praze, jakožto nástupnickou organizaci pražské židovské náboženské obce. ${ }^{41}$

37 Nelze však přehližžet fakt, že po vypuknutí 2. sv. války byla legální emigrace z Protektorátu téměř nemožná a její činnost tak spočívala především v postupném odebírání majetku Židům, kteří byli tímto způsobem „připravováni na legálni opuštěni Protektorátu“, k němuž došlo až během transportů.

38 Tzv. Vermögenserklärung.

39 Viz Nařízení o ztrátě protektorátního občanství ze dne 2. 11. 1942 (VOB1. RP, 1942, č. 45, s. 301), na základě kterého začalo na území Protektorátu platit modifikované 11. Nařízení k zákonu o říšském občanství ze dne 25. 11. 1941. Aby tato konstrukce mohla fungovat, byla aplikována právní fikce, na základě které se Terezín považoval za zahraniční území - viz KUKLÍK, $c . d$., s. 85.

40 Viz HÁJKOVÁ, A. Vznik a složení kartotéky židovských osob z let nacistické okupace. In: KÁRNÝ, M. LORENZOVÁ, E. (eds.). Terezinské studie a dokumenty 2000. Praha: Academia, 2000, s. 347.

41 Viz KUKLÍK, c. d., s. 125. 
Aby pražská židovská náboženská obec dostála svým nově uloženým povinnostem, musela v ní být vytvořena specializovaná oddělení, mezi která patřilo např. tzv. oddělení $\mathrm{H}$, jež převádělo židovský (hlavně nemovitý) majetek na Auswanderungsfond, ale především Treuhandstelle, ${ }^{42}$ jejímž úkolem bylo evidovat a spravovat majetek deportovaných. ${ }^{43} \mathrm{Na}$ seřadišti odevzdal každý účastník transportu pracovníkům Treuhandstelle vyplněné Vermögenserklärung a klíče od svého bytu. Byt byl následně otevřen, veškeré věci v něm zaevidovány, označeny transportním číslem a odvezeny do speciálních skladů, odkud byly jednotlivé předměty rozprodávány. ${ }^{44}$ Takto ,vyčištěný“ byt byl pak předán k dispozici Zentralstelle. Vzhledem k rozsahu zabavovaného majetku bylo třeba značného personálního aparátu, který přidělenou agendu rychle zpracovával a vytvářel o ní podrobnou evidenci, která však byla bohužel v závěru války z velké části zničena. ${ }^{45} \mathrm{~V}$ souvislosti s uměleckými předměty pak je ze struktury Treuhandstelle třeba zmínit tzv. klasifikační skupiny a odhadce uměleckých děl, kteří rozřazovali jednotlivé zabavené předměty do 4 kategorií. Podrobněji pak bude o těchto 4 kategoriích, které měly vliv na další osud konkrétních uměleckých děl a které byly používány i u předmětů ve správě Vermögensamtu, pojednáno níže.

\subsection{DISPOZICE S KONFISKOVANÝMI UMĚLECKÝMI DÍLY}

V předcházejícím textu byly popsány základní cesty, kterými se umělecká díla ocitla v dispozici orgánů a osob okupačního establishmentu. Podívejme se nyní stručně na to, jakým zpo̊sobem bylo s uměleckými díly v nacistických rukách dále nakládáno.

Jak jsme již výše zmínili, umělecká díla byla jednotlivými odhadci ${ }^{46}$ rozdělována do následujících 4 kategorií, jež měly podstatný vliv na jejich další osud:

1. umělecky zvláště cenné předměty, které byly shromažd'ovány bud' pro Führerovo muzeum v Linzi nebo směřovaly př́mo do nacistických soukromých sbírek;

2. předměty cenné pro českomoravský prostor, jež byly většinou rozděleny do protektorátních muzeí;

3. předměty umělecky cenné, které byly určeny k prodeji; a

4. předměty bez umělecké hodnoty, které byly bud' rozprodávány, nebo si je přímo ze skladů vybírali státní př́slušníci Říše pro vybavení svých bytů. ${ }^{47}$

42 Treuhandstelle byla zřizena z rozkazu Zentralstelle dne 13. 10. 1941, tj. jen 3 dny před prvním transportem.

43 Podrobnosti k činnosti Treuhandstelle viz KREJČOVÁ, H. - VLČEK, M. Návraty paměti: deponáty židovského majetku v Uměleckoprimmyslovém museu v Praze. Šenov u Ostravy: Tilia, 2007, s. 21.

$44 \mathrm{Z}$ pohledu uměleckých děl jsou důležité především sklady v pražských ulicích Dlouhá, Haštalská, V Kolkovně a Seifertova.

45 Šlo o aplikaci tzv. plánu ARLZ (Auflockerung - Räumung - Lähmung - Zerstörung), neboli taktiky spálené země. Toto ničení však naštěstí přežily některé zprávy z roku 1942, které se zmiňují o tom, že „, došlo k prevzetí přibližně 30.000 uměleckých předmětù “. Více viz KUKLÍK, c. d., s. 131.

46 Pro Treuhandstelle pracoval prof. K. M. Swoboda, pro Vermögensamt odhadoval Jindřich Baudisch. Více viz KREJČOVÁ, H. - KREJČA, O. Jindřich Baudisch a konfiskace uměleckých děl v protektorátu. Praha: Tilia, 2007.

47 Viz KUKLÍK, c. d., s. 131. 
Je velmi pravděpodobné, že jednotlivé odhady byly schválně podhodnoceny tak, aby díla skončila v zamýšlené skupině a mohla být ponechána na území Protektorátu nebo pod cenou rozprodána známým. ${ }^{48}$ Prodeje se pak uskutečňovaly bud' prostřednictvím firmy André, nebo starožitností Vollmer, později pak byla Vermögensamtem navázána spolupráce také se starožitnictvím Josefa Eichorna a jeho společností Bohemia Werkstäten. ${ }^{49} \mathrm{~V}$ neposlední řadě sloužila některá umělecká díla jako výzdoba protektorátních úřadů či soukromých rezidencí nacistických pohlavárů.

Muzeálně hodnotná umělecká díla, která nepatřila do 1 . kategorie, byla zařazována do veřejných galerií v Čechách a na Moravě. Sbírky současné NGP se tak obohatily o kresby a grafiky shromážděné v grafické sbírce Rudolfina, ${ }^{50}$ deponáty z Moderní galerie, jejíž sbírky se dostaly do správy Českomoravské zemské galerie v roce 1942, ale i o výhodné koupě, které byly vyhledávány na celoevropském trhu. Opomenout zde nelze ani konfiskované deponáty, které byly z ř́řského majetku dlouhodobě galerii zapůjčeny (nebo ponechány jako deponáty), a uchovaly se tak ve své celistvosti. ${ }^{51} \mathrm{~V}$ podobném režimu se podstatně rozrostly i sbírky ostatních muzeí, když např. obrazárnou při Moravském zemském muzeu byla dokonce uspořádána speciální výstava př́růstků z Engelmannovy a Löw-Beerovy kolekce. ${ }^{52}$ Stranou nemůžeme nechat ani zmínku o Ústředním židovském muzeu, které navazovalo na činnost původního pražského židovského muzea založeného roku 1906 a jež bylo z rozhodnutí Zentralamtu obohaceno o další historicky cenné předměty pocházející z mimopražských židovských obcí, ale i z původního majetku právnických a fyzických osob, které se podařilo nashromáždit prostřednictvím Treuhandstelle. O důvodech rozhodnutí okupační správy vybudovat muzeum můžeme dnes pouze spekulovat, faktem ale zůstává, že se tímto způsobem podařilo $v$ jeho sbírkách nashromáždit více než 20.000 předmětů, které byly přehledně katalogizovány a uchovány na jednom místě, což značně ulehčilo jejich poválečnou restituci. ${ }^{53}$

\section{ZÁVĚR}

Jak jsem již uvedla v úvodu, účelem této práce je základní shrnutí problematiky konfiskací uměleckých děl tak, aby mohla být prakticky využita při aplikaci zákona č. 212/2000 Sb. Obsahuje proto přehled základních právních předpisů, postupů a jednotlivých zainteresovaných institucí, se kterými je možné se při studiu problematiky tzv. looted art na území České republiky setkat.

Ačkoliv jsou veškeré informace zde uvedené pouze vodítkem $\mathrm{k}$ porozumění př́íhěhu provenience konkrétních uměleckých děl, měl by čtenář tohoto textu být schopen se při

48 Jen tak si lze např. vysvětlit, že na území Protektorátu zůstala zachována známá amfora z pálené hlíny, která patřila do sbírky Selmy Baštýřové.

49 Viz KUKLÍK, c. d., s. 133.

50 Založené v roce 1941 z inciativy prof. K. M. Swobody.

51 Více viz JANATKOVÁ - VLNAS, $c$. $d$.

52 Viz KUKLÍK, c. d., s. 129.

53 Více viz tamtéž, s. 135; a VESELSKÁ, M. Archa paméti: cesta pražského židovského muzea pohnutým 20. stoletím. Praha: Academia, 2012. 
svém archivním bádání rychle zorientovat $\mathrm{v}$ historických materiálech a snadno z nich vyvodit odpovídající závěry. Přesto je při praktickém použití této práce, $\mathrm{k}$ jejímuž textu se budu doufám nejenom já, ale i jeho čtenáři pravidelně vracet, třeba mít vždy na paměti, že osud jednotlivých uměleckých děl mohl být s ohledem na „divokost“ historického období různorodý a nemusí tak ve všech ohledech odpovídat základním tezím zde uvedeným. Tyto skutečnosti by však čtenáře neměli od zkoumání problematiky uloupeného umění odradit, ale naopak spíše motivovat k dalšímu bádání, které často připomíná detektivní práci. Na jejím konci totiž může stát úspěšné odškodnění obětí nebo alespoň jejich potomků.

Mgr. Zuzana Löbling

Právnická fakulta Univerzity Karlovy

z.krocilova@seznam.cz 